\title{
PETROPHYSICAL EVALUATION AND RESERVOIR HETEROGENEITIES AND THEIR IMPACT ON THE WATER MOVEMENTS. CASE STUDY: ABU MADI - EL QAR'A GAS FIELD, NILE DELTA, EGYPT
}

\author{
Said, Kh. and Nassar, Z.
}

\begin{abstract}
Abu Madi Formation of Abu Madi-El Qar'a gas field constitutes the main gas producing horizons in the onshore north Delta Basin, since 1975. The facies complexity of the reservoirs is the main controlling factor for the irregular and differential water movements. The results of interpretation of the available subsurface geological, geophysical and borehole data have been integrated in the form of petrographical, mineralogical, sedimentological and petrophysical studies to delineate the lithofacies, lithostratigraphy, depositional environments, structure and geometry of Abu Madi reservoirs in the study field.

Abu Madi Formation has been distinguished into a number of sand levels, named: Level III, III-A, II and I, where Levels II and III are the main pay zones in the study field. The optical microscopic examination indicates that these levels are partially of the same mineralogical composition. Meanwhile, the analyzed core samples showed anisotropic permeability with horizontal permeability values greater than vertical permeability (Cafiero, 1994).

In some sandstone levels, the permeability curves showed severe drop in the permeability values, with a remarkable reduction in porosity, sometimes, accompanied by slight increase in GR readings.

The sequence stratigraphy indicates that Abu Madi Formation; down cutting the Qawasim Formation and filled by braided alluvial deposits in its lower part (Level III), followed up section by Level III-A, which is estuarine to embayment sediments. Based on the characteristics of wireline logs, Level III is subdivided into three subdivisions, Lower, Middle and Upper units. The Lower and Middle units represent a channel fill phase while the upper unit is heterogeneous with rapid lateral facies change producing a poor lateral continuity (Alfy, 1992).

The stratigraphical and structural interpretations of the reflection seismic data indicate that the Sidi Salem and Qawasim formations are the sedimentation base of Abu Madi reservoir. Faulted and tilted blocks of the Qawasim and Sidi Salem formations gave rise to the irregular paleorelief, on which Abu Madi Formation deposited under a fluvial environment with tidal and marine-marginal influx (Sarha, 1994).

The dipmeter data helped to identify the significant textural and structural features and to identify the bed boundaries of Abu Madi levels. A number of isoparametric maps and cross sections have been constructed, throw light on the early unexpected water production and the rapid differential rises of the gas water contacts and their relationship with the reservoir heterogeneity in the studied field. However, recommendations concerning the problems of water advancement through Abu Madi reservoirs are given.
\end{abstract}

Keywords: Petrophysics, Reservoir heterogeneities, Abu Madi - El Qar'a, Nile Delta, Egypt.

\section{INTRODUCTION}

Abu Madi - El Qar'a gas field is the main gas producing onshore province in Egypt located in the northern part of the Nile Delta (Fig. 1). It was discovered in 1967 and put on production in 1975. More than 2/3 of the total gas production is mainly coming from Level III sand at the bottom of the Messinian Abu-Madi Formation. The hydrocarbons are mainly gas and condensate, entrapped in Abu-Madi sands and are sealed by Pliocene clays (the Kafr El Sheikh Formation). These sands were recognized to be 
associated with braided-fluvial distributary's channels and fluvial-dominated delta environment, the entrapment is by structural and stratigraphic elements.

Fig. 1: The geographical location of the Abu Madi El Qar'a gas field, Nile Delta, Egypt.

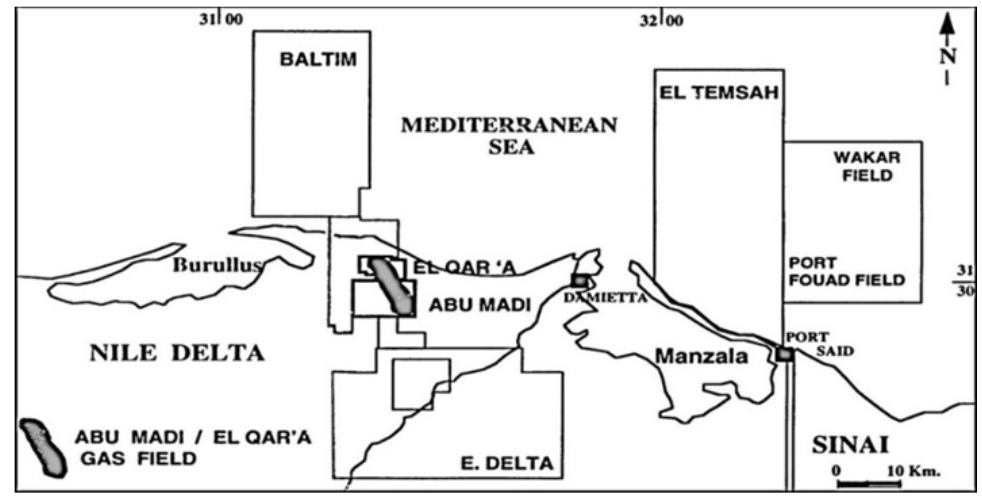

Geologically, Abu Madi Formation belongs to the complex depositional environment of the north Delta Basin. The sedimentological studies revealed the complexity of the depositional model, which is due to the stacking of the different channel fills sandstone bodies, and the internal primary structures within the individual channel, in a braided river system. The main stages of channel fills and alluvial fan deposits were recognized in the complex system.

The interface between the different sand bodies, where silty dirty facies are possibly predominant, might create some kind of transmissibility barriers. The geological, seismic and sedimentological data supported by the dynamic behavior of the producing wells helped in understanding the fluid movements within the reservoir and building a reasonable geological model that fits the regional geological framework. The evolution of the model is a good example, as a case history, of how the revision and the acquisition of new data dramatically changed the interpretation and the reconstruction of the field, from a simple structural trap to a complex structural/ stratigraphic combination.

Unexpected water breakthrough and differential water rises have been encountered in some wells. Transmissibility barriers between wells were introduced to account for pressure behavior and water movements, which might be related to the petrographical characteristics of the reservoir. The facies heterogenity is the main controlling factor for the water breakthrough across the field, which is reflected in irregular water movements.

The present study aims to evaluate the reasonable factors that controlling the water advance in Abu Madi - El Qar'a gas field. This will be done by integrating the available subsurface geological and geophysical data to delineate the geometry, lithofacies distribution and the depositional environments of Abu Madi sands. These aims are summarized as follows:

1- Analyzing of the petrophysical of Main level III of Abu Madi formation; and their influence on the reservoir production conditions and heterogeneity.

2- Determination of the differential water rises of the gas water contact.

3- Recommendations concerning the utilization strategy of the Reservoir.

Available data used in this study are represented by subsurface geological and geophysical information gathered from eight wells in El Qar'a lease and 20 wells in Abu Madi lease (Fig. 2). These data are represented by petrophysical data and E- logs, in addition to the composite logs.

Depending on the E-Logs data and using RIS (Reservoir Integrated System) the mapping system in this study; was created using Surfer8 (2016).

\section{EVALUATION OF MIDDLE LEVEL III SAND OF ABU MADI FORMATION}

\section{Subsurface distribution}

The depth contour map to the top of Level III-M (Fig. 3) shows values ranging from -3339m to $3236 \mathrm{~m}$ allover the study area. Level III-M is the second sub-level of Level III, so it reflects the paleorelief 


\section{Petrophysical evaluation and reservoir heterogeneities}

of Level III as a whole, but it is not recorded E, NE, W, S and SW wards of the study area. The depth decreases in a local paleohigh recording the value of $-3236 \mathrm{~m}$ E wards at the AM-1 well. By contrast, the depth increases gradually NW and SW wards of the area, recording the maximum value of $-3339 \mathrm{~m}$ at the EQ-3 well. However some local shallow and deep anomalies are recorded with the distribution pattern. This pattern may be affected by the paleorelief of Abu Madi Formation.

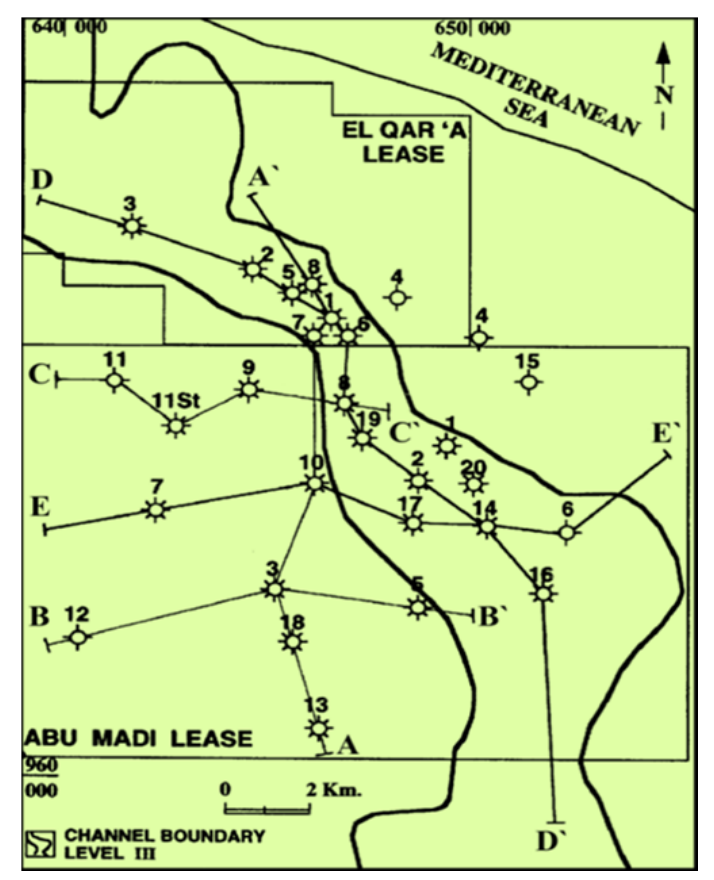

Fig. 2: Locations of the wells and profiles at the Abu Madi- El Qar'a field, Nile Delta.

\section{Shale distribution}

The volume of shale distribution map of Level III-U (Fig. 4) shows values ranging from $1 \%$ to $15 \%$ allover the study area, with a regular pattern and a tendency to decrease NE ward recording the minimum value of $1 \%$ at the AM- 1 and AM-2 wells. These values increase NW and SW wards recording the maximum value of $15 \%$ in the EQ-3 well. In general the wells along the main channel are recording the minimum shale percent compared with the Vsh cut off value (40\%).

\section{Porosity distribution}

The porosity map of Level III-M (Fig. 5) shows a regular distribution pattern with values ranging from $17.5 \%$ to $23 \%$ allover the study area, the minimum porosity value is $17.5 \%$ recorded at the EQ- 3 well, while the maximum value is $23 \%$ at the AM- 1 well.

\section{Water Saturation distribution}

The water saturation map of Level III-M (Fig. 6) shows an irregular pattern of distribution with values ranging from $19 \%$ to $64 \%$ allover the area. The minimum Sw values of $19 \%$ are recorded at the EQ-6 well, which indicates that the quality of the net bay hydrocarbons is preferable in this part of the field. The Sw values increase SW ward recording the maximum value of $64 \%$ at the EQ-2 well. The high water saturation with good porosity and a very low Vsh percent characterizing this level are very suitable factors making the reservoir ready for any water flooding or inundation from these directions.

\section{Net Pay distribution}

The net pay map of Level III-M (Fig. 7) shows an erratic NW-SE trending pattern of distribution with values ranging from $6 \mathrm{~m}$ to $82 \mathrm{~m}$ allover the area. The maximum net pay thickness of $82 \mathrm{~m}$ is recorded at the AM-14 well, the thickness decreases suddenly NW ward recording the minimum value of $6 \mathrm{~m}$ and $11 \mathrm{~m}$ at the AM-6 and AM-5 wells due to thinning of Level down dip. Generally this level is an economic reservoir, because of its very low Vsh value, thick net pay sand and moderate Sw value. This reservoir seems to be of very good porosity, low Vsh, moderate Sw and wide extension (Said, 2005). 
Said and Nassar
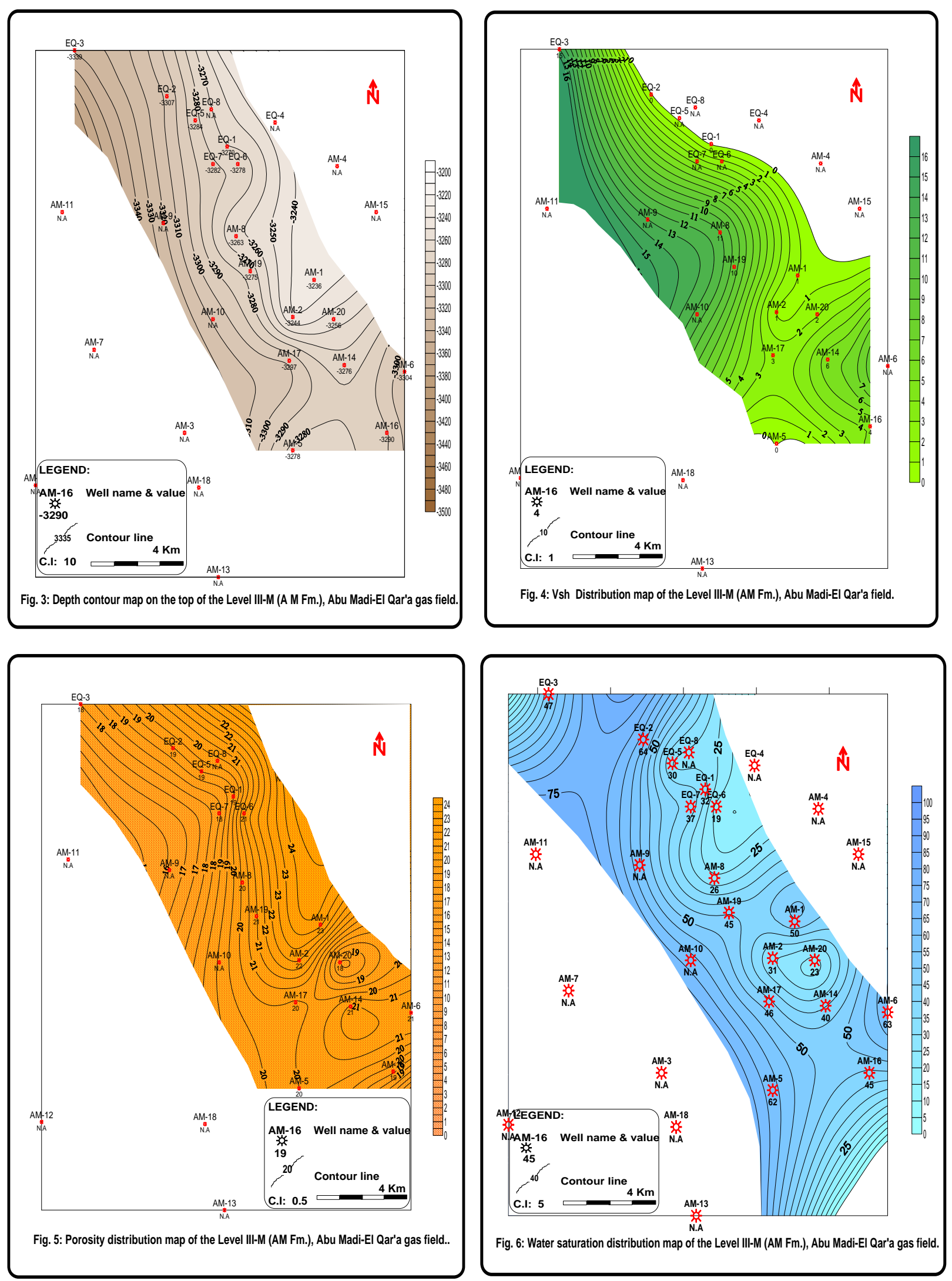


\section{Petrophysical evaluation and reservoir heterogeneities}

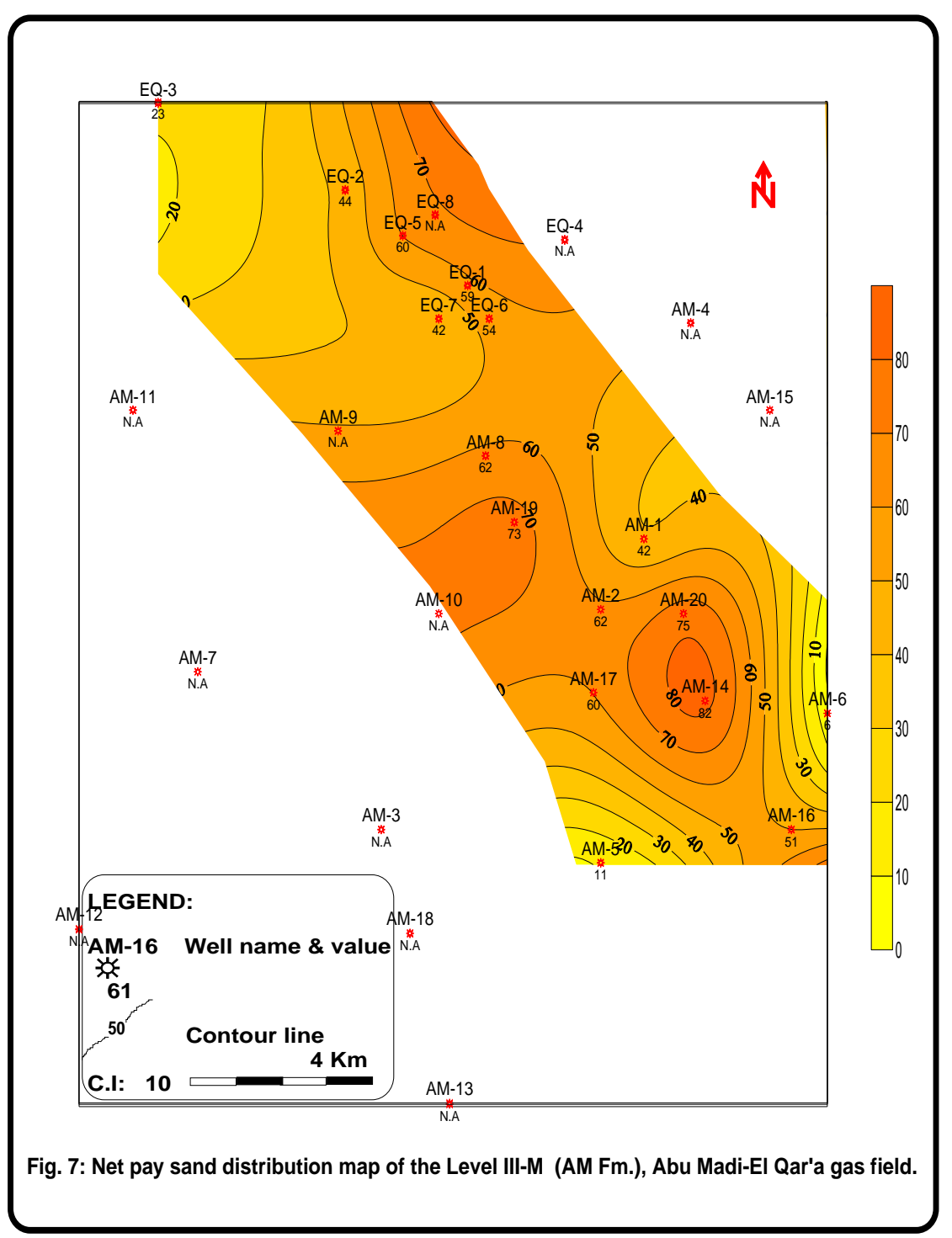

\section{RESERVOIR HETEROGENEITY AND PRODUCTION CONDITIONS}

The early unexpected water production and the rapid differential rises of the gas water contacts were not anticipated and influenced by the reservoir heterogeneity, water drive direction and activity and the structural setting of the producing pool.

\section{Reservoir Heterogeneity}

Permeability variation in any of the reservoirs is a function of their lithological and petrophysical characteristics. Reservoir heterogeneity were classified into four categories; megascale, macroscale, mesoscale and microscale. The scheme can be adapted to Level III Main of Abu Madi Formation, where only two kinds of heterogeneities were recognized, the macroscale and the microscale (Campbell, 1976).

\section{Macroscale Heterogeneity and its Effect on Water Breakthrough}

It is represented by the different genetic-origin sandstone bodies, the macroscale variations in reservoir properties among different sandstone bodies seem to have a great influence on its water flow regime (Hopkins et al., 1991). The interface between different units can have an intra-reservoir seal potential. Three wells have been closed in order to characterize the water breakthrough performance in the Main Level III in the northern part of the AM/EQ Field. The monthly production data of the three wells, arranged in E-W direction, are shown in (Fig. 8). 


\section{Said and Nassar}

The EQ-7 well has the shortest production history since the water production started early, close to the end of 1992. The well turned to production after water shut - off, but the water production killed the well again at the beginning of 1994. In the EQ-1 well a water breakthrough accompanied by gradual decrease in gas and condensate production, started in Feb. 1994. The lower perforations were isolated and good production rates were attained again. The water production increased gradually at the end of 1995.

In the EQ-8 well a steady gas and condensate production rates without any significant water cut have been maintained during its production history.

These problems of the hydrodynamic conductivity of the wells could be explained as follows: The EQ7 well is located in an older fluvial branch deposited by a NE paleo-current drainage system, paleohigh is partially isolating the area were siltstone and shale facies is expected to be deposited. The well watered out in 1994. The EQ-8 well has penetrated the stage I channel, which is considered as a separate branch of the main braided system. It was cut by the main channel system, stage II. The interface between the two channels might create a transmissibility barrier, resulting in different fluid contacts and pressure regime. In 1994, the gas water contact of the EQ-8 well was at depth $-3343 \mathrm{~m}$, while that one of the EQ-1 well was detected at depth $-3312 \mathrm{~m}$.

The nature of the barrier which was assumed in the area between the EQ-2 and EQ-5 wells to account for the different gas water contacts, could be explained in a sediment logical sense as follows: The massive pebbly coarse grained sandstones of the Main Level III of the EQ-2 well, which have been interpreted as alluvial fan deposits, are laterally interfingering with the cross bedded sandstone of the main fluvial valley of the EQ- 5 well. The interface between the two different sand bodies could create a transmissibility barrier which delayed the water to reach the EQ-5 well.

\section{Microscale heterogeneity and its effect on water breakthrough}

The analyzed core samples showed anisotropic permeability with horizontal permeability values up to an order of magnitude greater than vertical permeability values in general. In some sandstone laminae, the permeability curves showed sever drop in permeability values, with a remarkable reduction in porosity, sometimes, accompanied by slight increase in GR readings. These intervals represent either the basal siltstone which may or may not be present at the bases of individual channel deposits or the top set (parallel) laminae of the complete fluvial sequence in other ward, anisotropic permeability is the result of microscale heterogeneity in cross-stratified sandstone, deposited in braided to a low sinuosity river.

On the longitudinal section through the Main Level III channel, there is a difference in the gas water contacts between the EQ-5 well at depth $-3294 \mathrm{~m}$ and the EQ-1 well at depth $-3312.5 \mathrm{~m}$, this could be explained as a result of the microscale reservoir heterogeneity as follows:

The siltstone at the base of the individual channel deposits and channel system, together with the top set laminae of the complete fluvial system, are forming a network of impermeable to partially permeable very thin layers which are widespread allover the Main Level III reservoir. This microscale network could account for the delay of water to reach the EQ-1 well rather than the EQ-5 well.

Consequently it is expected to find several gas water contacts. The EQ-6 well was drilled in 1991 where no production from El Qar'a area was started yet, the open hole logs detected gas water contact at $333 \mathrm{~m}$ in this well, while the original one was recorded in the northern wells EQ-1 and EQ-5 at depth $3364 \mathrm{~m}$, this could be explained as follows: The continuous shale beds present at bottom of the Main Level III, divided the reservoir into entities which can be treated as hydraulic compartments. The water breakthrough are due to slumping and channeling of water where the water preferentially moved through lower permeable sand (Lower Level III) by passing the gas to the above sand Level (Main).

\section{Water drive direction and Activity}

The position of the well relative to the water front, is an important factor for the water breakthrough timing. Accordingly four wells have been chosen to characterize the water production performance the northern part of the AM/EQ Field. The monthly production data of the four wells, arranged in a north south direction, are shown in Figures (Fig. 9 and 10). 
Petrophysical evaluation and reservoir heterogeneities
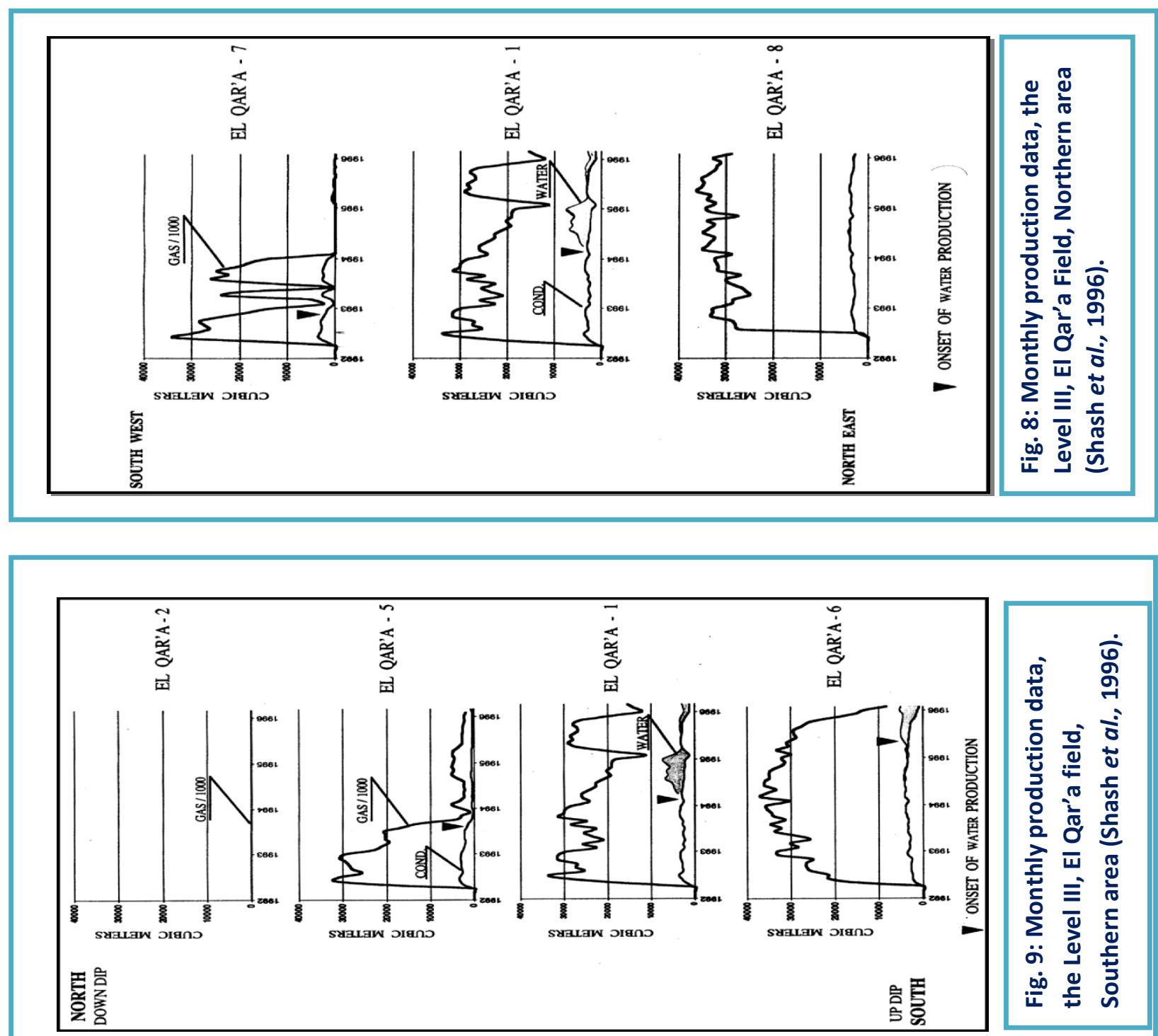

\begin{tabular}{|c|}
\hline 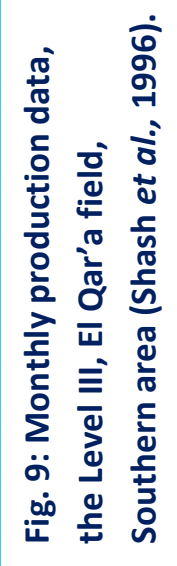 \\
\hline
\end{tabular}

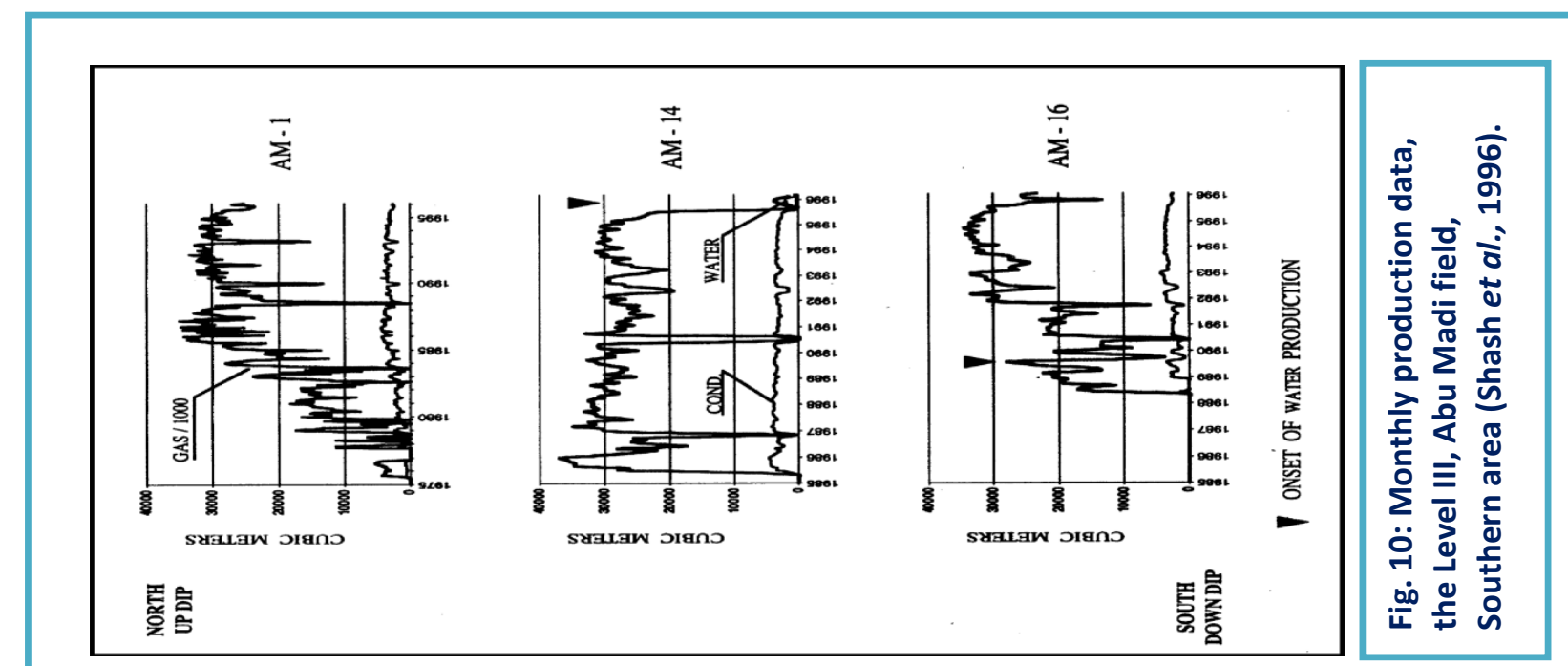




\section{Said and Nassar}

No production came through the northern down dip, the EQ-2 well in 1996 which was producing gas and condensate during1992. Southward, good production rates attained through the EQ-5 well until the onset of water production in July, 1993. More south ward in up-dip direction, a water break through was observed in the EQ-1 well in Feb. 1994.

The last the EQ-6 well, showed good steady gas and condensate production rates, without any significant water cut, during its production history until the water production in April 1995. Gradual increase in water production is accompanied by gradual declining in gas and condensate. Three wells have been selected to characterize the water production performance in the southern part of the field. The monthly production data of the wells arranged in a North - South direction in the southern down dip the AM-16 well, the onset of water production took place in 1989 and water shut-off process was carried out and the well turned to production. No more water production till the end of 1995. Good steady gas and condensate production rates lasted for 10 years. In the second the AM-14 well the water production started in June 1995. With respect to the north up-dip the AM-1, it was put on production since 1957 without any significant water production. Rapid breakthrough of water occurred in wells adjacent to water drive direction. The dynamic behavior on the north wells confirmed a strong aquifer support for the northern part of the field, while the southern part showed less water rise.

\section{OBSERVED RESPONSES TO WATER BREAKTHROUGH}

Shash et al., (1996) mentioned that, Level III gas production pool has been in production since 1985 . Through eleven years of gas production from Abu Madi area, there was no observed water rise of the original G.W.C. which was detected by evaluating the open hole logs of the AM-14 (1984) and AM-16 (1987) wells in the southern limb of Abu Madi-El Qar'a structure. The same G.W.C. depth was identified by El Qar'a-1 well (1985) in the northern limb. Pressure data and production tests at the three wells confirmed the contact depth.

The first indication of water table rise was observed in 1986 in well El Qara-2, when the electric logs determined a G.W.C. at depth $-3350 \mathrm{~m}$, some 14 meters shallower than the original condition. One year later, in 1987, another G.W.C. at depth -3361 m., was detected in the El Qar`a-3 well. Transmissibility barriers were introduced between wells to account for the differential water rise. No indication of water production in the southern limb.

Close to the end of 1989, an indication of water breakthrough occurred in the southern limb when the water cut started to increase gradually with time, in the producing AM-16 well. The water production reached $130 \mathrm{~m} / \mathrm{d}$. PLT (Production Log Tool) survey in June 1990 detected water influx from the lower perforations. A successful work over job was carried out to isolate the water zone and the G.W.C was assumed at depth $-3345 \mathrm{~m}$, also a TDT was recorded in well AM-19 which confirmed a 14 meters of water table rise to be at $-3350 \mathrm{~m}$. In El Qar'a- 2 well, the lower perforations produced water during the production test carried out in April 1991. The G.W.C. was assumed to be at depth $-3314 \mathrm{~m}$. Few months later in July 1991, El Qar`a-5 well was drilled and confirmed the original condition of the G.W.C. at depth $-3364 \mathrm{~m}$. Meanwhile, during the same year the EQ-6 well was drilled, a G.W.C. at depth -3333m was determined by log evaluation. Consequently, another transmissibility barrier was introduced in the area between the EQ-1 and EQ-6 wells. As a matter of fact, in 1991, differential water rise was responsible to get five G.W. contacts in Level III sand.

Production logs, PLT and TDT, recorded in 1994 in wells EQ-5, EQ-1, EQ-6 and AM-19, indicated farther water movement and the water levels became at depths $-3294 \mathrm{~m},-3309 \mathrm{~m},-3310 \mathrm{~m}$ and $-3340 \mathrm{~m}$, respectively. During the 3D reservoir study, and in order to reach a good match for pressure and water movements, transmissibility barriers were assumed between wells (Shash et al. 1996). Monitoring of the gas water contact through 1967-1992 has been presented in (Table 1).

Level III gas production pool, has been in production since 1985. Through eleven years of gas production from Abu Madi area, there was no observed water rise of the original G.W.C. which was detected by evaluating the open hole logs of the AM-14 (1984) and AM-16 (1987) wells in the southern limb of the AM/EQ structure. The same G.W.C. depth was identified by the EQ-1 well (1985) in the 


\section{Petrophysical evaluation and reservoir heterogeneities}

northern limb. Pressure data and production tests at the three wells confirmed the contact depth (cross section A-A', Fig. 11). The first indication of water table rise was observed in 1986 in the EQ-2 well, when the electric logs determined a G.W.C. at $-3350 \mathrm{~m}$, some 14 meters shallower than the original condition. One year later, in 1987, another G.W.C. at $-3361 \mathrm{~m}$ was detected in the well EQ-3 well. Transmissibility barriers were introduced between wells to account for the differential water rise. No indication of water production in the southern limb. Close to the end of 1989, an indication of water breakthrough occurred in the southern limb when the water cut started to increase gradually with time, in the producing the AM-16 well.

The water production reached $130 \mathrm{~m} / \mathrm{d}$. PLT survey in June 1990 detected water influx from the lower perforations. A successful work over job was carried out to isolate the water zone and the G.W.C. was assumed at depth $-3345 \mathrm{~m}$, also a TDT was recorded in the AM-19 well which confirmed a 14 meters of water table rise to be at depth $-3350 \mathrm{~m}$.

Table 1: G.W.C monitoring and Production data until January 1996 in Level III sand of Abu Madi Formation

\begin{tabular}{|c|c|c|c|c|c|c|c|}
\hline Well & Drilling & Production & Initial & Detected & Remarks & \multicolumn{2}{|c|}{ Cumulative Production } \\
\hline & & & & & & Gas/x $109 \mathrm{~cm}$ & Cond./x $103 \mathrm{~cm}$ \\
\hline AM-1 & $06 / 02 / 1967$ & Jul. 1975 & G.D.T & Unknown & No water cut & 4.868 & 585 \\
\hline AM-2 & $29 / 08 / 1967$ & Jan. 1975 & G.D.T & Unknown & No water cut & 4.927 & 585 \\
\hline AM-8 & $20 / 12 / 1980$ & Apr. 1982 & G.D.T & Unknown & No water cut & 3.789 & 435 \\
\hline AM-14 & $25 / 11 / 1984$ & Jun. 1985 & -3364 & -3345 & Assumd? & 3.332 & 385 \\
\hline EQ-1 & $06 / 07 / 1985$ & May. 1992 & -3364 & -3309 & PLT. 7/94 & 1.096 & 144 \\
\hline EQ-2 & $29 / 03 / 1986$ & ----- & -3350 & ----- & Watered out & ----- & ----- \\
\hline EQ-3 & $03 / 05 / 1987$ & $\begin{array}{ll}---- \\
\end{array}$ & -3361 & ----- & Watered out & ----- & $\begin{array}{ll}---- \\
\end{array}$ \\
\hline AM-16 & $03 / 09 / 1987$ & Jun. 1988 & -3364 & -3345 & PLT. 6/90 & 2.181 & 228 \\
\hline AM-17 & $08 / 09 / 1988$ & Nov. 1988 & -3363 & Unknown & No water cut & 2.267 & 250 \\
\hline AM-20 & $15 / 11 / 1988$ & Jan. 1989 & G.D.T & Unknown & No water cut & 2.406 & 266 \\
\hline AM-19 & $06 / 12 / 1988$ & Apr. 1989 & -3362 & -3340 & TDT. 6/94 & 2.244 & 247 \\
\hline EQ-5 & $18 / 07 / 1991$ & May. 1992 & -3364 & -3294 & PLT. 8/93 & 0.499 & 51 \\
\hline EQ-6 & $02 / 11 / 1991$ & May. 1992 & -3333 & -3309 & TMD. 6/94 & 1.326 & 139 \\
\hline EQ-7 & $13 / 01 / 1992$ & May. 1992 & -3364 & ---- & Watered out & 0.408 & 42 \\
\hline EQ-8 & $01 / 04 / 1992$ & May. 1992 & -3353 & Unknown & No water cut & 1.315 & 137 \\
\hline & & & & & & 30.658 & 3506 \\
\hline
\end{tabular}

In the EQ-2 well, the lower perforations produced water during the production test carried out in April 1991. The G.W.C. was assumed to be at depth $-3314 \mathrm{~m}$. Few months later in July 1991, the EQ-5 well was drilled and confirmed the original condition of the G.W.C. at depth $-3364 \mathrm{~m}$. Meanwhile, during the same year in Nov. 1991, the EQ-6 well was drilled, a G.W.C. at depth $-3333 \mathrm{~m}$ was determined by log evaluation. Consequently, another transmissibility barrier was introduced in the area between the EQ-1 and EQ-6 wells. As a matter of fact, in 1991, differential water rise was responsible to get five G.W. contacts in Level III.The production logs, PLT and TDT, which were recorded in 1994 for the EQ-5, EQ1, EQ-6 and AM-19 wells, indicated farther water movement and the water levels become at depths 3294m , -3309m, -3310m and -3340m, respectively.

\section{HYDROCARBON ENTRAPMENT, PRODUCTION AND RESERVES OPTIMIZATION}

Level II \& III sands of Abu Madi Formation are the main producing intervals in Abu Madi gas field. The gas in Level III, is trapped in a stratigraphic-structural combination trap. The longitudinal cross section (cross section A-A', Fig. 11) a long level III channel shows anticlinal structure, created by a local active paleo-high, which is located to the north of Abu Madi area. This paleo-high is controlling the overall Abu Madi structure. Level III deposited in the central and deeper part of the valley. A common spill point of the structure is located to the south of Abu Madi lease at depth $-3364 \mathrm{~m}$, which marks the original G.W.C. of the AM/EQ field. Level II has been completely filled with gas. The frequent facies variations within each reservoir units can create different anomalous gas water contacts and support the 
complex hydraulic scheme evident also from (RFT) Repeat Formation Test, static profiles and production behavior. Each gas pay unit as a thickness that can reach to $90 \mathrm{~m}$. The average thickness is $40 \mathrm{~m}$ for the upper level III, $70 \mathrm{~m}$ for the main and $50 \mathrm{~m}$ for the lower unit. Level II has an average thickness of $35 \mathrm{~m}$. but the best reservoir characteristics are related to the lower and main level III units of Abu Madi Formation.

The three sand units of level III produce almost $2 / 3$ of the overall gas production are dynamically in communication (Alfy et al., 1992). The average production was about 355 MMSCFD of gas and 3000 BOPD of condensate out of 15 wells in Dec.1996, and now about 154 MMSCFD of gas and 2436 BOPD of condensate out of 13 wells (Petrobel, 1999).

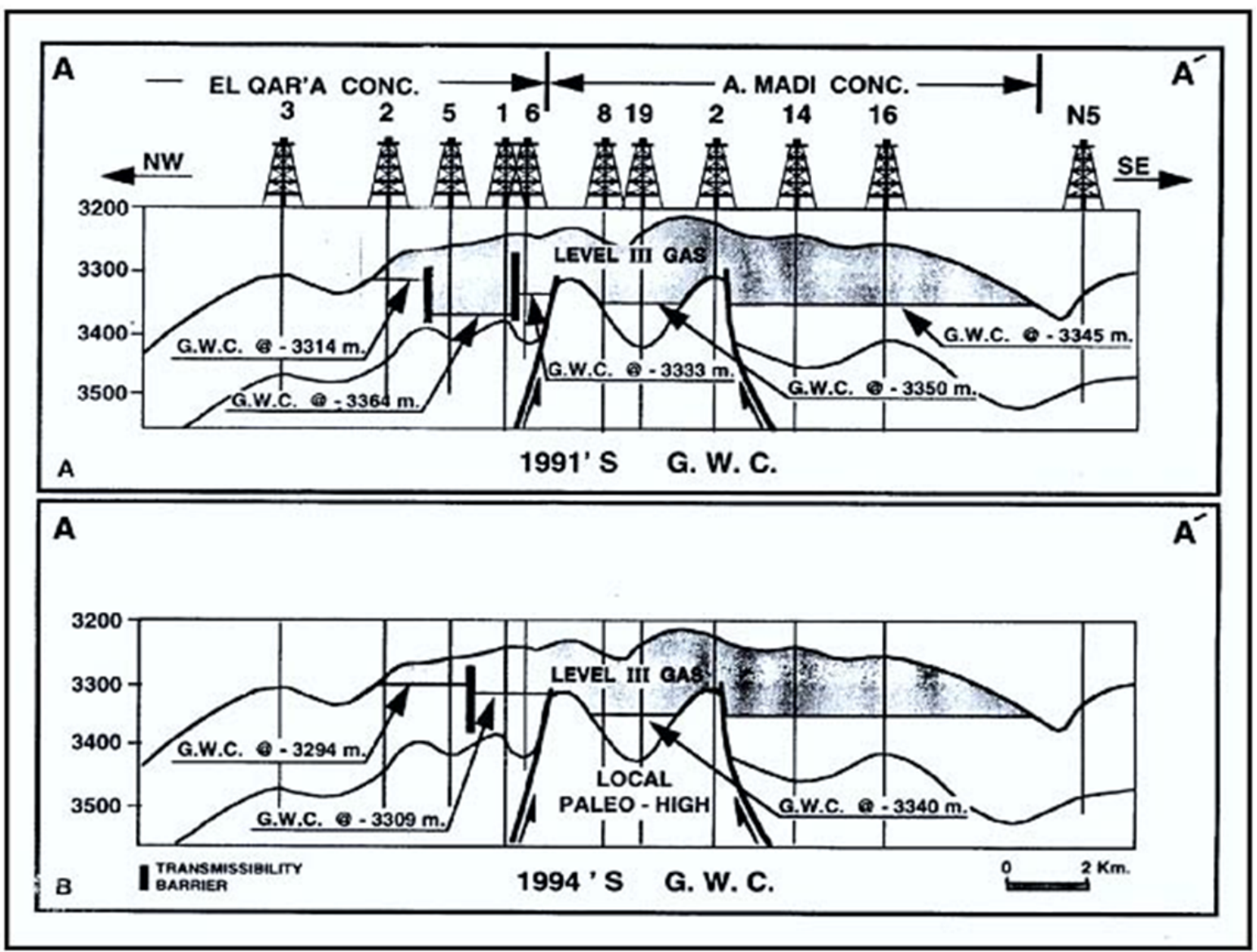

Fig. 11: cross section along the profile A-A showing that the deposition of the Level III controlled by an active paleo-high and two small basins creating different anomalous G.W.C

\section{SUMMARY AND RECOMMENDATIONS}

This study aims to study some of the reasonable factors that controlling the water advance in the Main level III of Abu Madi sands for this field (8 wells in El Qar'a lease and 20 wells in Abu Madi lease); by integrating and evaluating the available subsurface geological and Petrophysical parameters supported by the dynamic behavior of the fluids.

Based on the characteristics as well as E-logs (resistivity); the Middle Level III sands are considered to be of a good quality reservoir, because they represent the channel fill phase and characterized by a good lateral continuity, high sand shale ratio and their geometry is a sheet like bodies.

The analyzed core samples showed anisotropic permeability with horizontal permeability values greater than vertical permeability. In some sandstone laminae, the permeability curves showed severe drop in the permeability values, with a remarkable reduction in porosity, sometimes, accompanied by slight 


\section{Petrophysical evaluation and reservoir heterogeneities}

increase in GR readings. These intervals represent either the basal siltstone, which may or may not be present at the bases of individual channel deposits or the top set (parallel) laminae of the complete fluvial sequence.

The petrographical studies showed a recognizable diagenetical events; such as the occurrence of a Fechlorite rim around the detrital grain contemporaneously or just after the deposition. This first event will have an impact on all the subsequent diagenetic evolution. The most important effects of this diagenesis are to create a resistance to the mechanical compaction and to prevent the precipitation of cements such as quartz overgrowths in the pore space. On the other hand the rim effect is very small on the permeability because its thickness is so reduced, and due also to the relative coarse grain size of the sediments and porosity (Cafiero, 1994).

The subsurface structural setting of the area played an important role in sizing the depositional sand bodies of Abu Madi Formation with its gas and condensates. Three main structural trends influenced the area: NW-SE (Gulf oblique) faults, NNE-SSW (Aqaba oblique) faults and WNW, E-W \& ENE faults at the northern margin of the "Hinge Zone"

Abu Madi El Qar'a gas field lies in the northern onshore area in the central sub-basin, where the favorable conditions for the hydrocarbon accumulations, are present. The positive structural shape of the field seems therefore to be the result of the local presence of paleo-highs like this located between Abu Madi and El Qar'a fields.

Faulted and tilted blocks of the Qawasim and Sidi Salem formations gave rise to the irregular paleorelief, These blocks create the shoulders which limit the extension of the alluvial plane and the interabasinal high areas and control the deposition of the overlying formations such as Abu Madi Formation which shows a thickness variation of its levels, specially in level III; because it is the most affected by intrabasinal highs.

The Main level III reflects the structural/stratigraphic complication of the field, due to the internal primary structures within the individual channel and the interface of the silty facies of the different channels, which created some kind of transmissibility barriers. This complexity is the main controlling factor for the irregular and differential water movements.

The Main level III deposited as a braided alluvial system in the main channel of the paleovalley in the first phase, and the erosional events in the second one, whisch characterized by cut-off processes of previous fluvial deposits, mostly in the El Qar'a area. The hetereogenity of the sand bodies is a key element for the gas distributions in the reservoirs. The production behavior seems to support the recent reconstruction model.

The macroscale heterogeneity is represented by the different genetic-origin sandstone bodies, which have a great influence on the water flow regime. The interface between different units can have an intrareservoir seal potential. The anisotropic permeability is the result of the microscale heterogeneity in crossstratified sandstone bodies.

Based on this study, recommendations concerning the problems of water advancement through Abu Madi reservoirs are:

1- Earlier studying of the sedimentology and structure of the field, with particular emphasis to the direction of water movement and reserves.

2- Exploitation of the reservoir that suffer from an early water breakthrough from its upper most part and production with a high rate

\section{AKNOWLEDGEMENTS}

This contribution reflects the unflagging efforts of Mr. Mohamed Zaki Nassar and Prof. Dr. Fouad Shaaban, therefor I dedicated my research to their amazing patience and tolerance.Gratitude is wished to extend the appreciation to Belayim Petroleum Company (Petrobel) and all the study team for their input and permission to release this information. 
Said and Nassar

GLOSSARY

ABBREVIATIONS USED IN TEXT

\begin{tabular}{|l|l|l|l|}
\hline \multicolumn{1}{|c|}{ Term } & \multicolumn{1}{c|}{ The Term Description } & \multicolumn{1}{c|}{ Term } & \multicolumn{1}{c|}{ The Term Description } \\
\hline AM & Abu Madi & TDT & Thermal Decay Time \\
\hline EQ & El Qar'a & Sw & Effective water saturation \\
\hline IEOC & Itaian - Egyptian oil Company & N.P & Net Pay interval \\
\hline G.W.C & Gas / Water Contact & Av. Phi Pay & Average porosity in the pay interval. \\
\hline G.D.T & Gas Down To & Vsh & Wet shale volum. \\
\hline M. Miocene & Middle Miocene & Gr Curve & Value of the gamma ray in the zone of interest. \\
\hline Fm. & Formation & S.S.L & Subsea level \\
\hline Fe-chlorite & Ferric-chlorite & TVDss & True vertical depth \\
\hline E.log & Electrical logs & RFT & Repeat Formation Tester \\
\hline m / d & meter / day & MMSCFD & Million stander cubic feet per day \\
\hline PLT & Production Log Tool & BOPD & Barrel of oil per day \\
\hline
\end{tabular}

\section{REFERENCES}

Abu El Ella, R., (1990): Maturation history of Neogene - Quaternary sediments, Nile Delta basin, Egypt. AAPG Bulletin, 47(1), 77-84.

Agip, 1994: Abu Madi / El Qar'a field, level III Geophysical and Geological study. unpublished Internal reports.

Alfy, M., Polo, F. and Shash, M., (1992): The Geology of Abu Madi Gas Field, Nile Delta, Egypt, EGPC 11th Exploration and Production Conference.

Cafiero, M., (1994): Agip S.P.A Abu Madi / El Qar'a level III sedimentological study.

Campbell, C.V, (1976): Reservoir geometry of a fluvial sheet sandstone, AAPG, 60, 1009-1020.

Hopkins, J. C., Wood, J.M. and Krause, F. F., (1991): Waterflood Response of Reservoir in an Estuarine valley fill: Upper Mannville G, U, and W pools, Little Bow field, Alberta, Canada. AAPG, V.75, No.6 P.1064-1087.

Sarhan, M., Hemdan, K., (1994): North Nile Delta structural setting and trapping mechanism. Egypt. 12th EGPC Exploration and Production conference, Cairo.

Shash, M., Rizk, R. and Zaki, M., (1996): Depositional model and its impact on the water breakthrough in Abu Madi El Qar'a gas field, Nile Delta, Egypt, EGPC 13rd Exploration and Production conference, Cairo.

Said, K., Nasar Z. and Essa Gh., (2005): Sedimentological studies and reservoir characteristics of Abu Madi formation and their influence on the water advance in Abu Madi -El qar a gas field, Nile Delta, Egypt.

Petrobel, (1994): Periodical Production Report; Abu Madi / El Qar'a level III. 